\title{
A Comparison of the Policies in Taiwan and South Korea for Developing a "World-Class University" and their Outcomes
}

\author{
Dr. Yueh-Chun Huang \\ Professor and Dean, \\ Teachers College, National Chiayi University \\ Dr. Ru-Jer Wang \\ Professor and President, \\ National Taichung University of Education
}

\begin{abstract}
In recent decades numerous nations around the world have been making major efforts in developing so-called "world-class universities," and Taiwan and South Korea are no exceptions. During the past ten years Taiwan adopted its "Five Year-50 Billion Excellence Initiative," and South Korea has implemented BK21 PLUS. In this paper we examine and compare the relevant policies affecting the development of world-class universities in Taiwan and South Korea. The purposes of this study are: 1) to review the backgrounds behind the policies in Taiwan and South Korea relating to the development of world-class universities; 2) to present an overview of the relevant policies in Taiwan and South Korea; 3) to examine and compare the outcomes of these polices; and 4) to provide suggestions based on the findings of this study. The methods employed in this study include documentary and secondary data analysis and comparative study. The main findings were as follows: 1) additional expenditures have produced additional outcomes; 2) when examining the outcome of a particular policy, it is necessary to pay attention to unexpected effects; 3 ) when examining policy effects, it is necessary to take into account a diverse range of evidence; and 4) there is no magic prescription for developing a world-class university.
\end{abstract}

Keywords: world-class university; Taiwan; BK21 PLUS

\section{BACKGROUND}

The competition to develop a world-class university (WCU) has become a global phenomenon in the past decade, and numerous governments have put the development of world-class higher education and research systems at the heart of their national development policies (THE World University Rankings, 2018; Zaini, Lyan, \& Rebentisch, 2015).

In line with this trend, Taiwan has initiated its "Five year - 50 Billion Excellence Initiative," and South Korea has implemented BK21 PLUS (Brain Korea 21 Program for Leading Universities \& Students). The development of WCUs has been high on the policy agenda of various stakeholders across the globe in the past decade. A range of development strategies have been adopted and various reforms have been implemented in an increasing number of nations, regions, and higher education institutions in both developed and developing countries. Such a "world-class" movement has also been intensified by the proliferation of international league tables (Academic Ranking of World Universities, 2015, p. 1). Indeed, discussions of WCUs have become an academic cottage industry in the 21st century. Yet the concept of a WCU is a recent phenomenon (Altbach \& Balan, 2007; Altbach, Salmi, \& Jamil, 2011). However, definitions of the term are complex and at times contradictory (Kirby \& Joycelyn, 2016). Striving for excellence is not a bad thing, and competition may spark improvement. However, putting too 
much stress on attaining world-class status may harm an individual university or an academic system by diverting energy and resources from more important goals (Altbach, 2004). The commonalities across various conceptions of "world-class" include productive faculty, excellent students, flexible administration, plentiful funding, and international engagement (Kirby \& Joycelyn, 2016).

In this study we compare the policies in Taiwan and South Korea for developing a WCU. Specifically, the purposes of this study are: 1) to review the backgrounds behind the policies in Taiwan and South Korea relating to the development of world-class universities; 2) to present an overview of the relevant policies in Taiwan and South Korea; 3) to examine and compare the outcomes of these polices; and 4) to provide suggestions based on the findings of this study.

The methods employed in this study include documentary and data analysis and comparative study.

\section{THE RELEVANT LITERATURE AND THEORETICAL CONSIDERATIONS}

\section{The characteristics of a "world-class" university}

Altbach (2003) asserts that the characteristics that distinguish a WCU remain elusive. This view is also held by Li (2012), who contends that the very concept of a WCU is "ambiguous, uncertain, and contested, varying from one context to the next." What then might be the characteristics of a WCU? By combining the viewpoints of Altbach and Salmi (2011) and Shattock (2017), the five main characteristics of a WCU can be said to be as follows: 1) a high concentration of talent (faculty members and students); 2) abundant resources offering a rich learning and research environment; 3) favorable governance policies that encourage leadership, strategic vision, innovation, and flexibility; 4) a long history and a prominent physical location; and 5) the existence of an external political climate that gives full license to free expression and academic freedom.

Salmi (2009) presents a list of the 24 characteristics of a WCU, stating that it: 1) Has an international reputation for its research; 2) Has an international reputation for its teaching; 3 ) Has a number of research stars and world leaders in their fields; 4) Is recognized not only by other WCUs (for example, U.S. Ivy League) but also outside the world of higher education; 5) Has a number of world-class departments (that is, not necessarily all); 6) Identifies and builds on its research strengths and has a distinctive reputation and focus (that is, its "lead" subjects); 7) Generates innovative ideas and produces basic and applied research in abundance; 8) Produces groundbreaking research output recognized by peers and prizes (for example, Nobel Prize winners); 9) Attracts the most able students and produces the best graduates; 10) Can attract and retain the best staff; 11) Can recruit staff and students from an international market; 12) Attracts a high proportion of postgraduate students, both taught and research; 13) Attracts a high proportion of students from overseas; 14) Operates within a global market and is international in many activities (for example, research links, student and staff exchanges, and throughput of visitors of international standing); 15) Has a very sound financial base; 16) Receives large endowment capital and income; 17) Has diversified sources of income (for example, government, private companies sector, research income, and overseas student fees); 18) Provides a high-quality and supportive research and educational environment for both its staff and its students (for example, high-quality buildings and facilities / high-quality campus); 19) Has a first-class management team with strategic vision and implementation plans; 20) Produces graduates who end up in positions of influence and / or power (that is, movers and shakers such as prime ministers and presidents); 21) Often has a long history of superior achievement (for example, the Universities of Oxford and Cambridge in the United Kingdom 
and Harvard University in the United States); 22) Makes a big contribution to society and our times; 23) Continually benchmarks with top universities and departments worldwide; and 24) Has the confidence to set its own agenda

Similarly, a study by THE World University Rankings (2018) states that the average top 200 university: 1) Has a total annual income of $\$ 751,139$ per academic (compared with $\$ 606,345$ for a top 400 university); 2) Has a student-to-staff ratio of 11.7:1 (compared with 12.5:1 for a top 400 university); 3) Hires 20 percent of its staff from abroad (compared with 18 percent for a top 400 university); 4) Has a total research income of $\$ 229,109$ per academic (compared with $\$ 168,739$ for a top 400 university); 5) Publishes 43 percent of all its research papers with at least one international co-author (compared with 42 percent at a top 400 university); and 6) Has a student body made up of 19 percent international students (compared with 16 percent at a top 400 university).

Moreover, Vest (2018) believes that the factors which contribute the most to the excellence and success of US higher education include: 1) The diversity of institutions-from small liberal arts colleges to large public and private universities-allows students to select the school that best matches their needs; 2) New assistant professors have freedom to choose what they teach as well as research; 3) Our research universities weave together teaching and research in ways that bring freshness, intensity, and renewal to both activities; 4) We welcome students, scholars, and faculty from abroad. Their intellectual and cultural richness helps define our institutions; 5) Support of frontier research in our universities has long been an important responsibility of the federal government, which awards grants to researchers on the basis of their merit in a competitive marketplace of ideas; 6) A tradition of philanthropy, fostered by US tax law, encourages alumni and others to support our colleges and universities; 7) Scholarship funds they provide allow talented students from families of modest means to attend even the most costly schools; and 8) Open competition for faculty and students drives excellence. Such factors could be integrated into the cultural and political contexts of other nations and perhaps be improved on.

\section{The Relevant Policies and their Results in Taiwan}

A WCU is commonly regarded as a nation's most prestigious research university and is essential to a nation's competitiveness in the global knowledge economy (Wang, Cheng, and Liu, 2012), and is also regarded as a central part of any academic system (Cheng \& Liu, 2014). Salmi (2009) identified three major approaches that governments desiring to set up such institutions could follow. The first consists of upgrading a few existing universities that have the potential to excel (picking winners). The second relies on encouraging several existing institutions to merge and transform into a new university that would achieve the type of synergies corresponding to a world-class institution (hybrid formula). Finally, a government might decide to create a WCU from scratch (clean-slate approach). It appears that both Taiwan and South Korea have taken the first approach. In order to enhance the nation's international competitiveness in higher education, in 2006 Taiwan's Ministry of Education (MOE) implemented its "Plan for Developing WCUs and Top Research Centers." In 2009 the title of the Plan was changed to "Towards the Top University Plan," which continued until March 2016. Every year, the government has provided about US\$312,500,000 (NT\$100 billion) in funding for the above plan. The purposes of this plan were as follows (Department of Higher Education, MOE, 2015):

1) To accelerate the internationalization of top universities and to widen students' international perspective.

2) To enhance the quality of university research and to strengthen its international academic visibility. 
3) To actively recruit and support excellent students and faculty.

4) To strengthen the cooperation between academia and industry, to upgrade industry, and to improve national competitiveness.

5) To encourage academia's responsiveness to societal and industrial needs.

According to the MOE (2015), 12 universities received grants between 2011 and 2015 as part of the Towards the Top University Plan: National Taiwan University, National Cheng Kung University, National Tsing Hua University, National Central University, National Sun Yat-Sen University, National Yang Ming University, National Chung Hsing University, Chang Gung University, National Chengchi University, National Taiwan University of Technology, and National Taiwan Normal University, as shown in Figure 1.

Figure 1. Taiwanese Universities Awarded Grants from the Towards the Top University Plan

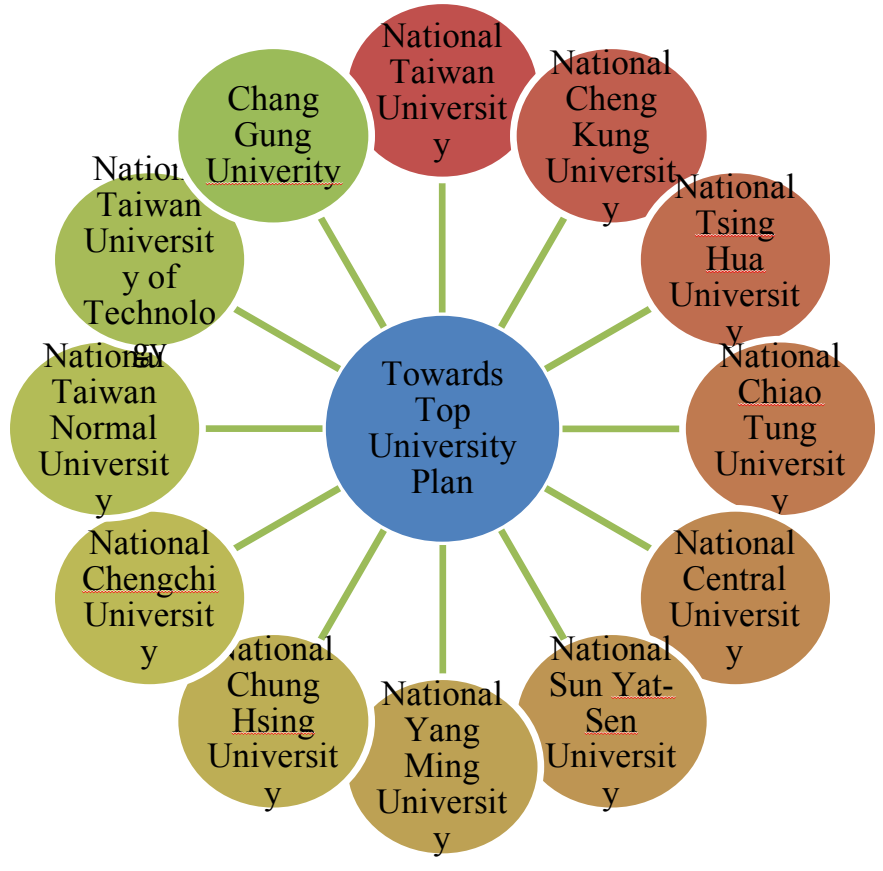

Source: Department of Higher Education, Ministry of Education, 2015

\section{The Relevant Policies and their Results in South Korea}

According to South Korea's MOE (2015), the highlights of the two phases of BK21 PLUS can be summarized as follows:

- First phase (1999-2005)

o Budget: US\$1.34 billion

O Participation: 564 centers and teams and 89,366 students over the 7-year period

o Support: US\$400 per month for master's degree students, US\$600 for doctoral degree students, US $\$ 1,250$ for post-doctoral researchers, and US $\$ 2,500$ for contract professors

o Achievements:

- Number of BK21 science and technology SCI-level papers published: 3,765 (1998) $\rightarrow 7,281$ (2005)

- $\quad$ SCI national ranking: $16^{\text {th }}(1998) \rightarrow 12^{\text {th }}(2005)$

- Number of PhDs awarded in science and technology (1999-2005): 6,602

- Quality improvement as indicated by the average impact factor per article: 1.9 $(1999) \rightarrow 2.43$ (2005)

Second phase (2006-2012)

○ Goal (2012): 
- Nurture ten top research-oriented universities in key fields

- Attain top-ten ranking in terms of SCI-paper publication

- Become one of the world's ten most advanced countries in terms of technology transfer from academia to industry $(10 \%$ in $2004 \rightarrow 20 \%$ by 2012$)$

O Budget: US $\$ 290$ million per year, US\$2.3 billion in total

O Participation: 74 universities, 244 centers, 325 project teams, and 20,000 graduate students per year

o Support: US $\$ 500$ per month for master's degree students, US\$900 for doctoral degree students, US\$2,000 for post-doctoral researchers, US\$2,500 for contract professors

o More than $\$ 100$ million of investment from industry

o "Regional Graduate School of Excellence" program

- Third phase (2013-2019)

o Goal (2019):

- Nurture top research-oriented universities so as to increase the number of universities ranked among QS's first 200 universities from 6 in 2012 to 11 in 2019

- Enhance the quality of teaching, research, and creative programs so as to improve from $30^{\text {th }}$ in 2011 to $20^{\text {th }}$ in 2019 in terms of the SCI impact factor

○ Budget: US $\$ 2.526$ billion per year

o Participation: 500 project teams and 15,000 graduate students per year

\section{METHODOLOGY}

Documentary and secondary data analysis and comparative study were employed in this study. The questions to be answered in this study are as follows:

1) What are the policies for developing a WCU in Taiwan and the Republic of Korea?

2) What have been the results of these policies in terms of the QS World University rankings for 2012-2018?

3) What have been the results in terms of the 2018 Best Global Universities Rankings by US News?

4) What have been the results in terms of the Times Higher Education Asia University Rankings 2018?

For answering the above questions, we first referred to the related official documents of the governments of Taiwan and South Korea. We then analyzed the data from the QS (Quacquarelli Symonds) World University Rankings and the US News 2018 Best Global Universities Rankings (US News rankings). There are three main world university rankings: the Times Higher Education World University Rankings (THE rankings), the Academic Ranking of World Universities (ARWU), and the QS World University Rankings. Amongst these, in this study only data from the QS World University Rankings was used. One of the main difficulties of using secondary data is adjusting data collected for the original purpose to suit the needs of a different study. This difficulty was solved by undertaking a comprehensive consideration of the data. Of course, when employing the QS rankings as data, one must bear in mind the main criticisms facing the QS rankings, especially its reliability. Many educators question the value of rankings and argue that they can measure only a narrow slice of what quality higher education is about. QS's methodology seems to be particularly controversial, however, due in large part to its greater reliance on reputational surveys than on other criteria. Combined with its survey of employers, which counts for ten percent of the overall ranking, reputational indicators account for half of a university's QS ranking. Also, QS has offices in five countries providing a host of services to colleges, including consulting services and recruitment fairs. Thus critics have 
raised questions about the potential for conflict of interest when the same company calculates the ranking and offers consulting services for individual universities. However, Sowter found that strict internal walls prevent one part of the business from bleeding into another (Soh, 2013; Redden, 2013). Smith (2006) asserts that secondary analysis facilitates triangulation with data from other sources, for instance, comparing survey results with census data or comparing the findings of earlier studies with more recent research. With these considerations in mind, we analyzed data from both the QS rankings and US News rankings.

\section{ANALYSIS AND DISCUSSION}

\section{Top universities in Taiwan in terms of the QS World University Rankings}

The following are the top 200 universities in Taiwan in the QS rankings. As can be seen from Table 1, from 2012 to 2018, only National Taiwan University and National Tsing Hua University were included in the top 200 universities.

Table 1. Taiwanese universities in the top 200 of the QS World University Rankings, 2012-2018

\begin{tabular}{lll}
\hline Year & Rank & University \\
\hline \multirow{2}{*}{2012} & 80 & National Taiwan University \\
& 192 & National Tsing Hua University \\
\cline { 2 - 3 } & 82 & National Taiwan University \\
\hline 2014 & 799 & National Tsing Hua University \\
\cline { 2 - 3 } & 167 & National Taiwan University \\
\hline 2016 & 70 & National Tsing Hua University \\
& 155 & National Taiwan University \\
& 68 & National Tsing Hua University \\
\hline 2017 & 151 & National Taiwan University \\
& 76 & National Tsing Hua University \\
\hline \multirow{2}{*}{2018} & 161 & National Taiwan University \\
& & Source Qs Top Universitives 2018 \\
\hline
\end{tabular}

Source: QS Top Universities, 2018

\section{Top universities in South Korea in terms of the QS World University Rankings}

In 2012, six South Korean universities were listed among the top 200 universities in the QS rankings (see Table 2 and Figure 3 for details). Table 2 shows that, in terms of rank, there has been some progress among top universities, such as Seoul National University (from 37 in 2012 to 36 in 2018) and the Korea Advanced Institute of Science and Technology (from 63 in 2012 to 41 in 2018). The number of top-200 universities increased from 6 in 2012 to 7 in 2018. 
Table 2. South Korean universities in the top 200 of the QS World University Rankings, 20122018

\begin{tabular}{|c|c|c|}
\hline Year & Rank & University \\
\hline \multirow[t]{6}{*}{2012} & 37 & Seoul National University \\
\hline & 63 & Korea Advanced Institute of Science and Technology \\
\hline & 97 & Pohang University of Science and Technology \\
\hline & 112 & Yonsei University \\
\hline & 137 & Korea University \\
\hline & 179 & Sungkyunkwan University \\
\hline \multirow[t]{6}{*}{2014} & 35 & Seoul National University \\
\hline & 60 & Korea Advanced Institute of Science and Technology \\
\hline & 107 & Pohang University of Science and Technology \\
\hline & 114 & Yonsei University \\
\hline & 145 & Korea University \\
\hline & 162 & Sungkyunkwan University \\
\hline \multirow[t]{6}{*}{2015} & 31 & Seoul National University \\
\hline & 51 & Korea Advanced Institute of Science and Technology \\
\hline & 86 & Pohang University of Science and Technology \\
\hline & 106 & Yonsei University \\
\hline & 116 & Korea University \\
\hline & 140 & Sungkyunkwan University \\
\hline \multirow[t]{7}{*}{2016} & $\overline{36}$ & Peoul National University \\
\hline & 43 & Korea Advanced Institute of Science and Technology \\
\hline & 87 & Pohang University of Science and Technology \\
\hline & 105 & Yonsei University \\
\hline & 104 & Korea University \\
\hline & 118 & Sungkyunkwan University \\
\hline & 193 & Hanyang University \\
\hline \multirow[t]{7}{*}{2017} & 35 & Seoul National University \\
\hline & 46 & Korea Advanced Institute of Science and Technology \\
\hline & 83 & Pohang University of Science and Technology \\
\hline & 112 & Yonsei University \\
\hline & 98 & Korea University \\
\hline & 106 & Sungkyunkwan University \\
\hline & 171 & Hanyang University \\
\hline \multirow[t]{7}{*}{2018} & 36 & Seoul National University \\
\hline & 41 & Korea Advanced Institute of Science and Technology \\
\hline & 71 & Pohang University of Science and Technology \\
\hline & 106 & Yonsei University \\
\hline & 90 & Korea University \\
\hline & 108 & Sungkyunkwan University \\
\hline & 155 & Hanyang University \\
\hline
\end{tabular}




\section{Top universities in Taiwan and South Korea in terms of the US News Best Global}

\section{University Rankings}

In the 2018 US News rankings, eight South Korea universities and two Taiwanese universities were ranked in the top 500 (see Table 4 for details).

Table 4. South Korean and Taiwanese universities in the top 500 of the 2018 US News Rankings

\begin{tabular}{|l|l|c|c|}
\hline Country & University & Global Rank & Global Score \\
\hline South Korea & $\begin{array}{l}\text { Seoul National } \\
\text { University }\end{array}$ & 123 & 63.2 \\
\hline Taiwan & $\begin{array}{l}\text { National Taiwan } \\
\text { University }\end{array}$ & 166 & 60.3 \\
\hline South Korea & $\begin{array}{l}\text { Korea Advanced } \\
\text { Institute of Science } \\
\text { and Technology }\end{array}$ & 200 & 57.9 \\
\hline South Korea & $\begin{array}{l}\text { Sungkyunkwan } \\
\text { University }\end{array}$ & 274 & 53.5 \\
\hline South Korea & $\begin{array}{l}\text { Porea University } \\
\text { Science and } \\
\text { Technology }\end{array}$ & 296 & 52.5 \\
\hline South Korea & Yonsei University & 307 & 49.1 \\
\hline Taiwan & $\begin{array}{l}\text { National Tsing Hua } \\
\text { University }\end{array}$ & 370 & 47.9 \\
\hline South Korea & $\begin{array}{l}\text { Ulsan National } \\
\text { Institute of Science } \\
\text { and Technology }\end{array}$ & 392 & 44.1 \\
\hline South Korea & Hanyang University & 479 & \\
\hline
\end{tabular}

Sources: U.S. News, 2018 


\section{Top universities in Taiwan and South Korea in terms of the Times Higher Education Asia} University Rankings

Finally, in the Times Higher Education Asia University Rankings 2018, 16 South Korea universities and nine Taiwanese universities were ranked amongst the top universities in Asia: (See Table 5 for details).

Table 5. South Korean and Taiwanese universities in the Times Higher Education Asia University Rankings 2018

\begin{tabular}{|c|c|c|}
\hline Country & University & Rank \\
\hline South Korea & Seoul National University & 9 \\
\hline South Korea & $\begin{array}{l}\text { Korea Advanced Institute of } \\
\text { Science and Technology }\end{array}$ & 10 \\
\hline South Korea & $\begin{array}{l}\text { Pohang University of Science } \\
\text { and Technology }\end{array}$ & 12 \\
\hline South Korea & Sungkyunkwan University & 13 \\
\hline South Korea & $\begin{array}{l}\text { Yonsei University (Seoul } \\
\text { campus) }\end{array}$ & 20 \\
\hline South Korea & $\begin{array}{l}\text { Ulsan National Institute of } \\
\text { Science and Technology }\end{array}$ & 22 \\
\hline South Korea & Korea University & 24 \\
\hline Taiwan & National Taiwan University & 26 \\
\hline Taiwan & National Tsing Hua University & 36 \\
\hline South Korea & Hanyang University & 38 \\
\hline South Korea & $\begin{array}{l}\text { Gwangju Institute of Science } \\
\text { and Technology }\end{array}$ & 39 \\
\hline South Korea & Kyung Hee University & 40 \\
\hline Taiwan & $\begin{array}{l}\text { National Taiwan University of } \\
\text { Science and Technology } \\
\text { (Taiwan Tech) }\end{array}$ & 42 \\
\hline Taiwan & $\begin{array}{l}\text { National Chiao Tung } \\
\text { University }\end{array}$ & 48 \\
\hline South Korea & Chung-Ang University & 50 \\
\hline Taiwan & $\begin{array}{l}\text { National Cheng Kung } \\
\text { University }\end{array}$ & 58 \\
\hline South Korea & Ewha Womans University & 65 \\
\hline Taiwan & $\begin{array}{l}\text { China Medical University, } \\
\text { Taiwan }\end{array}$ & 72 \\
\hline Taiwan & $\begin{array}{l}\text { National Taiwan Normal } \\
\text { University }\end{array}$ & 74 \\
\hline South Korea & University of Ulsan & 77 \\
\hline Taiwan & Taipei Medical University & 83 \\
\hline South Korea & Konkuk University & 95 \\
\hline South Korea & Pusan National University & 97 \\
\hline South Korea & Sejong University & 100 \\
\hline Taiwan & $\begin{array}{l}\text { National Yang-Ming } \\
\text { University }\end{array}$ & 107 \\
\hline
\end{tabular}

Sources: Times Higher Education Asia University Rankings 2018

Retrieved from https://www.timeshighereducation.com/world-universityrankings/2018/regional-ranking\#!/page/0/length/25/sort_by/rank/sort_order/asc/cols/stats 


\section{CONCLUDING REMARKS}

Based on the above analysis, three conclusions can be made as follows:

First of all, it is understandable that extra money has produced additional outcome. Phil Baty (2018), editor of the Times Higher Education World University Rankings, said:

Top-quality universities come in many different shapes and sizes, and there is no single model of excellence. . . . First, you need serious money. Significant financial resources are essential to pay the salaries required to attract and retain the leading scholars and to build the facilities needed. Second, providing an intimate and intensive teaching environment for students, where they can expect to truly engage with leading academic staff, can really help. Finally, and perhaps most importantly, a world-class university must be genuinely international. It must be a magnet for the planet's most talented staff and students, wherever they happen to come from; it must bring people together from a range of different cultures and backgrounds to tackle shared global challenges; and it must work and think across national borders.

However, resources for higher education may be unequally distributed to higher education institutions if we pay too much attention to a limited number of so-called top universities. This may result in a lack of resources among the remaining universities and then damage to the soundness of higher education as a whole.

In other words, overemphasis on the creation of a WCU may result in the stratification of higher education, making it difficult to develop a healthy system of higher education for all students. It is worth noting that international rankings clearly favor research-intensive universities over first-rate institutions that enroll primarily undergraduate students. As countries embark on the task of establishing WCUs, they may also want to consider the desirability of creating, besides research universities, other excellent universities which meet the wide range of education and training needs that a tertiary education system is expected to satisfy (Salmi, 2015).

First, it is suggested that we pay attention to quality and competitiveness within the entire higher education system, rather than to just a tiny number of so-called top universities. Otherwise, blindly pursuing the goal of creating a WCU may weaken the quality of higher education as a whole.

Second, when examining the outcome of the relevant policy, we need to pay attention to any unexpected collateral effects. From the above illustrations it is evident that in both Taiwan and South Korea the relevant policies have led to a positive result in terms of number and rank. However, two related issues need to be taken into account. The first is related to whether or not extra money will be available for continuing the funding of interns. The second is related to what will happen to those universities if they don't receive the extra money.

Thirdly, when we examine the policy effects, more diverse evidence is needed. In this study, amongst the three main rankings, we have only collected information from the QS ranking. It is suggested that in future research information should be collected from the other two main world university rankings.

Finally, there is no magic prescription for developing a WCU (Ahmed, 2015; Salmi, 2009). The transformation of the university system cannot take place in isolation. A long-term vision for creating a WCU-and its implementation-should be closely articulated with (Ahmed, 2015): 1) the country's overall economic and social development strategy; 2) ongoing changes and planned reforms at the lower levels of the education system; and 3) plans for the development 
of other types of higher education institutions to build an integrated system of teaching, research, and technology-oriented institutions.

\section{References}

Academic Ranking of World Universities (2015). Introduction, 6th International Conference on World-Class Universities, 1-4 November 2015, Shanghai, China. Retrieved from http://www.shanghairanking.com/wcu/

Ahmed, H. (2018). Strategic Approach for Developing World-Class Universities in Egypt. Journal of Education and Practice, 6(5). Retrieved from https://files.eric.ed.gov/fulltext/EJ1083601.pdf

Altbach, P. G., \& Balan, J. (2007). Transforming Research Universities in Asia and Latin America. In P. G. Altbach \& Jorge Balán (Eds.), World Class Worldwide. Baltimore, MD: Johns Hopkins Press.

Altbach, P. G. (2004). The Costs and Benefits of World-Class Universities. Academe, 90(1), 20-23.

Altbach, P. G., \& Salmi, J. (2011). The Road to Academic Excellence: The Making of World Class Research Universities. Washington, DC: World Bank.

Asia University Rankings 2015 (2015). Retrieved from https://www.timeshighereducation.com/worlduniversity-rankings/2015/regional-ranking\#!/page/0/length/25

Brain Korea 21 Plus (2015). Retrieved from https://bkplus.nrf.re.kr/index.jsp

Chattock, M. (2017). The "World Class" University and International Ranking Systems: What are the Policy Implications for Governments and Institutions? Policy Reviews in Higher Education, 1(1), 4-21.

Cheng Ying, \& Liu Niancai (2014) (Eds.). How World-Class Universities Affect Global Higher Education: Influences and Responses. Rotterdam/Boston/Taipei: Sense Publishers.

Department of Higher Education, Ministry of Education (2015). The Competitiveness of Higher Education. Retrieved from http://140.113.40.88/edutop/index_1.php (In Chinese)

Kirby, W. C., \& Joycelyn, W. E. (2016). “World-Class” Universities: Rankings and Reputation in Global Higher Education. Harvard Business School Background Note 316-065, October 2015 (Revised November 2016).

Li Jun (2012). World-class Higher Education and the Emerging Chinese Model of the University. Prospects, 42(3), 319-339.

Ministry of Education, Republic of Korea (2015). Summary of BK21 and NURI Projects. Retrieved from http://english.moe.go.kr/web/1710/en/board/enview.do?bbsId=258\&boardSeq=1174\&mode=view

QS Top Universities (2018). Retrieved from https://www.topuniversities.com/

Redden, E. (2013). Scrutiny of QS Rankings. Retrieved from

https://www.insidehighered.com/news/2013/05/29/methodology-qs-rankings-comes-under-scrutiny

Salmi, J. (2009). The Challenge of Establishing World-Class Universities. Washington, DC: The World Bank.

Smith, E. (2006). Using Secondary Data in Educational and Social Research. Berkshire, England: Open University Press.

Soh, K. C. (2013). Rankings Mislead with Unstandardised Scores. Retrieved from

http://www.universityworldnews.com/article.php?story=20130627211805732

Taiwan Ministry of Education (2015). Towards the Top University Plan (2015). Retrieved from

http://www.edu.tw/pages/detail.aspx?wid=c0746986-1231-4472-abce-

5 c5396450ba9\&Node $=2302 \&$ Page $=16787$ (In Chinese)

THE World University Rankings (2018).The formula for a world-class university revealed. Retrieved from https://www.timeshighereducation.com/world-university-rankings/news/the-formula-for-a-world-classuniversity-revealed

Times Higher Education (THE) World University Rankings (2018). Asia University Rankings 2018. Retrieved from https://www.timeshighereducation.com/world-university-rankings/2018/regional-

ranking\#!/page/0/length/25/sort_by/rank/sort_order/asc/cols/stats

U.S. News (2018). Best Global Universities. Retrieved from https://www.usnews.com/education/best-globaluniversities

Vest, C. M. (2018).World Class Universities: American Lessons. International Higher Education, international issue, 6-7. 
Wang Qi, Cheng Ying, \& Liu Niancai (EDs.) (2012). Building World-Class Universities: Different Approaches to a Shared Goal. Rotterdam: Sense Publishers.

Wang Qinghui, Wang Qi, \& Liu Niancai (2011). Chapter 2: Building World-Class Universities in China. In P. G. Altbach and J. Salmi (Eds.), The Road to Academic Excellence. The Making of World-Class Research Universities (pp. 33-62). Washington, DC: The World Bank.

Wikipedia (2015). Towards the Top University Plan. Retrieved from

https://zh.wikipedia.org/wiki/\%E9\%82\%81\%E5\%90\%91\%E9\%A0\%82\%E5\%B0\%96\%E5\%A4\%A7\%E5\%AD \%B8\%E8\%A8\%88\%E7\%95\%AB (In Chinese).

Zaini, R., Lyan, D., \& Rebentisch, E. (2015). Start-up Research Universities, High Aspirations in a Complex Reality: A Russian Start-up University Case Analysis Using Stakeholder Value Analysis and System Dynamics Modeling. Triple Helix, 2(4). DOI: https://doi.org/10.1186/s40604-014-0016-8. 